\section{Analysis of lymphocyte T(CD4+) cells expression on severe early childhood caries and free caries}

\author{
Muhammad Luthfi, ${ }^{1}$ Priyawan \\ Rachmadi, ${ }^{2}$ Aqsa Sjuhada Oki, ${ }^{1}$ \\ Retno Indrawati, ${ }^{1}$ Agung Sosiawan, ${ }^{3}$ \\ Muhaimin Rifa' ${ }^{4}$ \\ ${ }^{1}$ Department of Oral Biology; \\ ${ }^{2}$ Department of Dental Material; \\ ${ }^{3}$ Department of Public Health, Faculty \\ of Dental Medicine Universitas \\ Airlangga, Surabaya; ${ }^{4}$ Department of \\ Physiology, Cell Culture and Animal \\ Develepment, Faculty of Sciences, \\ Brawijaya University, Malang, \\ Indoensia
}

\begin{abstract}
Early childhood caries (ECC) is still one of the many diseases found in children throughout the world. Cariogenic bacteria are a significant risk factor for ECC associated with early colonization and high levels of cariogenic microbes (Streptococcus mutans, S. mutans). Lymphocyte T (CD4 $\left.{ }^{+}\right)$ cells known as helper $\mathrm{T}$ cells, are effector cells for mediated host immunity. Naive $\mathrm{T}$ cells $\left(\mathrm{CD}^{+}\right)$must be activated to initiate effector function. This activation occurs through interaction with professional antigen-presenting cells (pro-APC), especially dendritic cells that lead to intracellular pathways that regulate $\mathrm{T}$ cell receptor (TCR) more specifically against antigen in T cells. Lymphocyte cells from samples were collected from severe early childhood caries (S-ECC) and Free caries aged 5 to 6 years. The subjects were instructed to gargle 10 $\mathrm{mL}$ of sterile $\mathrm{NaCl} 1.5 \%$ solution for $30 \mathrm{sec}-$ onds, and expectorate it into a sterile glass then analyzing $\mathrm{T}$ lymphocyte cell $\left(\mathrm{CD}^{+}\right)$ expression using flow cytometry. Lymphocyte $\mathrm{T}\left(\mathrm{CD}^{+}\right)$cell expression at $\mathrm{S}$ ECC (6.2525 \pm 64482$)$ while in free caries $(8.4138 \pm 1.10397)$ with $\mathrm{P}$-value $(\mathrm{P}=0.000)$. Conclusion of lymphocyte $\mathrm{T}\left(\mathrm{CD}^{+}\right)$cells expression at S-ECC is lower than that occurring in free caries.
\end{abstract}

\section{Introduction}

Early childhood caries (ECC) is still one of the many diseases found in children throughout the world. ECC does not only affect the oral health of children, but also general body health. ${ }^{1}$ ECC not only involves pain in the oral cavity, orthodontic problems, and damage to the enamel, but can also cause problems with food intake, speech and increased risk for caries development in permanent teeth. ${ }^{2}$ Early loss of primary teeth often leads to orthodontic problems in adult life. ${ }^{3}$

ECC is the most common childhood chronic disease, with almost 1.8 billion new cases per year globally ${ }^{4}$ which occurs in about $37 \%$ of children aged $2-5$ years in America States and up to $73 \%$ of preschoolers who are socially economically disadvantaged in developing and industrialized countries. ${ }^{5}$ ECC is also highly prevalence in preschool children living in developing countries like Indonesia ${ }^{6}$ the prevalence of ECC in group of children aged 6 months-3 years at Gunung Anyar SurabayaIndonesaia was $30.8 \%$, while the prevalence was $29.2 \%$ S-ECC. ${ }^{7}$ ECC was defined as the presence of $\geq 1$ decay, loss (due to caries), or full tooth surface in primary teeth in children 71 months of age or younger. S-ECC occurs in children $<3$ years with $\geq 1$ rot, missing (due to caries), or full tooth surface and in children aged 4-6 years with high caries score. ${ }^{8}$ ECC and S-ECC remain serious problems that occur in school children in Xinjiang. Lower sociodemographic status (disadvantaged areas, low-educated mothers, low-income families, caregivers with cavities), risky dietary behavior (consumption of high frequency sweets, frequent meals before going to bed), oral hygiene behaviors that are at risk of ECC such as at what age start to brush teeth and use of dental services (past dental visits, parents who have received oral health care instructions) are associated with an increased risk of ECC and S-ECC.

Severe early childhood caries (S-ECC is an infectious disease that is a public health problem in the world, in spite of ongoing control efforts. The purpose of the host immune response during infection is to clear pathogens that attack with limited tissue damage. Both innate cells and adaptive $\mathrm{T}$ cells play a key role in clearing pathogens directly through the release of proinflammatory cytokines and the activity of cytotoxic $\mathrm{T}$ lymphocytes (CTL). In addition, helper (Th) T cells and regulatory Treg cells are required for antibodies secreted by plasma cells and immunomodulatory cytokines (eg, IL-10), respectively. In recent years, the role of the new set of Th cells, including follicular $\mathrm{T}$ cells namely $\mathrm{Th} 17$, Th22, in regulating anti-infective immunity, has become very important, because they play an important role in the development and outcome of disease. ${ }^{9}$

Cluster of differentiation 4 (CD4) coreceptor expressed in a subset of T cells, plays a role in differentiation, migration and cytokine expression. ${ }^{10} \mathrm{~T}$ cells involved in
Correspondence: Muhammad Luthfi, Department of Oral Biology, Faculty of Dental Medicine Universitas Airlangga. Jl. Mayjend. Prof.Dr. Moestopo 47 Surabaya 60132, Indonesia.

Tel.: +6281357898957.

E-mail: m.luthfi@fkg.unair.ac.id

Key words: Severe early childhood caries, adaptive immunity, lymphocyte $\mathrm{T}(\mathrm{CD} 4+)$ cells expression.

Contributions: ML: Study conception, study design, intelectual content, literature research, data acquisition, data analysis, manuscript review, guarantor; PR: Study concept, clinical studies, experimental studies, data analysis, manuscript review; ASO: Study design, literature research; RI: Experimental studies, data analysis. statistical analysis; AS: Data interpretation, manuscript preparation, manuscript editing; MR: Study concept, clinical studies, experimental studies.

Conflicts of interest: The authors declare no conflict of interest.

Funding: The authors would like to thank Directorate of Research and Community Services of Directorate General of Research and Development Strengthening from Ministry of Research, Technology and Higher Education of the Republic of Indonesia for the grant funding provided for this research.

Acknowledgements: The authors would like to thank Prof. Muhaimin Rifa'i, PhD.Med.Sc for the help in conducting this research.

Conference presentation: Part of this paper was presented at INSBIOMM conference 2728 August, 2019

Received for publication: 17 February 2020. Accepted for publication: 1 July 2020.

This work is licensed under a Creative Commons Attribution-NonCommercial 4.0 International License (CC BY-NC 4.0).

${ }^{\circ}$ Copyright: the Author(s), 2020

Licensee PAGEPress, Italy

Infectious Disease Reports 2020; 12(s1):8760 doi:10.4081/idr.2020.8760

antigen recognition, $\mathrm{CD} 4$ stabilizes the ternary complex pMHC-TCR and CD4 recruits Lck kinase to phosphorylate ITAM and initiate intracellular signaling during activation of $\mathrm{T}$ cells induced by antigens. ${ }^{11}$ CD4 was originally described as an adhesion molecule that enhances contact between $\mathrm{T}$ cells and precenting cell antigens. In their pillar work, Doyle and Strominger found direct correlations of other specific $\mathrm{T}$ cells involved in interactions ${ }^{12}$ CD4 binds MHCII molecules with 
very low 3D affinity. ${ }^{13}$ Based on the above background, the researchers wanted to analyze how the expression of $\mathrm{T}$ lymphocytes (CD4+) cells in S-ECC and caries-free.

\section{Materials and Methods}

This study was an analytic observational study, with cross-sectional analysis on two groups of sample; children with S-ECC and free caries children. All the procedures in this study had been reviewed and approved by the Health Research Ethical Clearance Commission of Universitas Airlangga, Faculty of Dental Medicine, with certificate no 209/HRECC. FODM/IX/ 2017.

\section{Lymphocyte Isolation}

Lymphocyte cells from saliva obtained by instructing the subject to rinse with 10 $\mathrm{mL}$ of $1.5 \%$ sterile $\mathrm{NaCl}$ solution while rinsing, but not swallowed for 30 seconds, then expectorated in sterile glass. This procedure was repeated 4 times. The sample was then centrifuged at $450 \mathrm{~g}$ for $15 \mathrm{~min}$ utes, at $40 \mathrm{C}$. The centrifugation pellets were then mixed with $2 \mathrm{~mL}$ of RPMI medium, then the samples were vortexed. ${ }^{14}$ The results of the filter in the form of cell suspension are then calculated using a hemocytometer.

The same volume of cell suspension and $0.2 \%$ dye of trypan blue were mixed in the eppendorf tube and in doing vortex. The same suspension aliquots $(20 \mu \mathrm{L})$ were added to both chamber haemocytometers and observed under a microscope (10X objective). The mixture is withdrawn with capillary action. The cells are counted in an area of 16 squares which is equivalent to the number of cells x104/mL. Only translucent cells are counted in the box. The number of cells per $\mathrm{mL}$ is calculated using the following formula:

Cell $/ \mathrm{mL}=$ average number of cells per primary square $\mathrm{x} 10^{4} \mathrm{x}$ dilution factor

\section{Lymphocyte Culture and Cultivation}

Lymphocyte cells $\left(3 \times 10^{5}\right.$ cells $\left./ \mathrm{mL}\right)$ were cultured in the tissue culture flask (Greiner) $75 \mathrm{~cm}^{2}$ with complete culture medium (RPMI-1640, 10\% fetal calf serum (FCS), and 1\% penicillin/streptomycin) in $5 \% \mathrm{CO} 2$ and atmosphere humidity $95 \%$ at $37^{\circ} \mathrm{C}$ for 24 hours. The cultures were checked daily to observe the changes in color, turbidity, density, and growth pattern using inverted light microscope (Nikon Eclipse Ts2R).

\section{CD4+ Expression Analysis}

The expression of $\mathrm{CD}^{+}{ }^{+}$were observed by means of flow cytometry method adapted from Luthfi et al. ${ }^{15}$ Fluorescein isothiocyanate (FITC), phycoerythrin (PE), allophycocyanin (APC), Peridinin chlorophyll protein (PerCP), PerCP-Cy5.5-conjugated monoclonal antibodies (mAbs) from Becton Dickinson (San Jose, CA, USA). The optimum concentration of mAbs were determined for each $\mathrm{mAb}$ by means of titration. Flow cytometry can both measure and analyze the physical characteristics of a particle such as cell since it can flow into the fluid stream through the light. The light scattered by the cell can be used to analyze changes in size, granularity, internal complexity, and relative fluorescence intensity. Flow cytometry analysis is conducted to discover the immunomodulatory pattern of lymphocyte using conjugated monoclonal antibody.

Salivary lymphocytes were moved into FACS tube and washed with $4 \mathrm{~mL}$ Dulbecco Phosphate Buffer Saline (DPBS) and centrifuged for 5 minutes at 2000rpm; the supernatant was subsequently removed. The pellet in DPBS were once again washed and centrifuged at $1800 \mathrm{rpm}$ for 8 minutes. The cells were stained using yellow viability dye $(1 \mathrm{~mL}$ stain $/ 1000 \mu \mathrm{L}$ DPBS $)$ then vortexed and incubated at $4{ }^{\circ} \mathrm{C}$ for 15 minutes. The cells were subsequently washed with $4 \mathrm{~mL}$ DPBS and 1\% FCS, centrifuged at $1800 \mathrm{rpm}$ for 8 minutes and the supernatant was removed. The cells were stained with the exact required volume of $\mathrm{mAbs}$, followed by vortexed and incubated in refrigerator for 20 minutes. After washed in cold

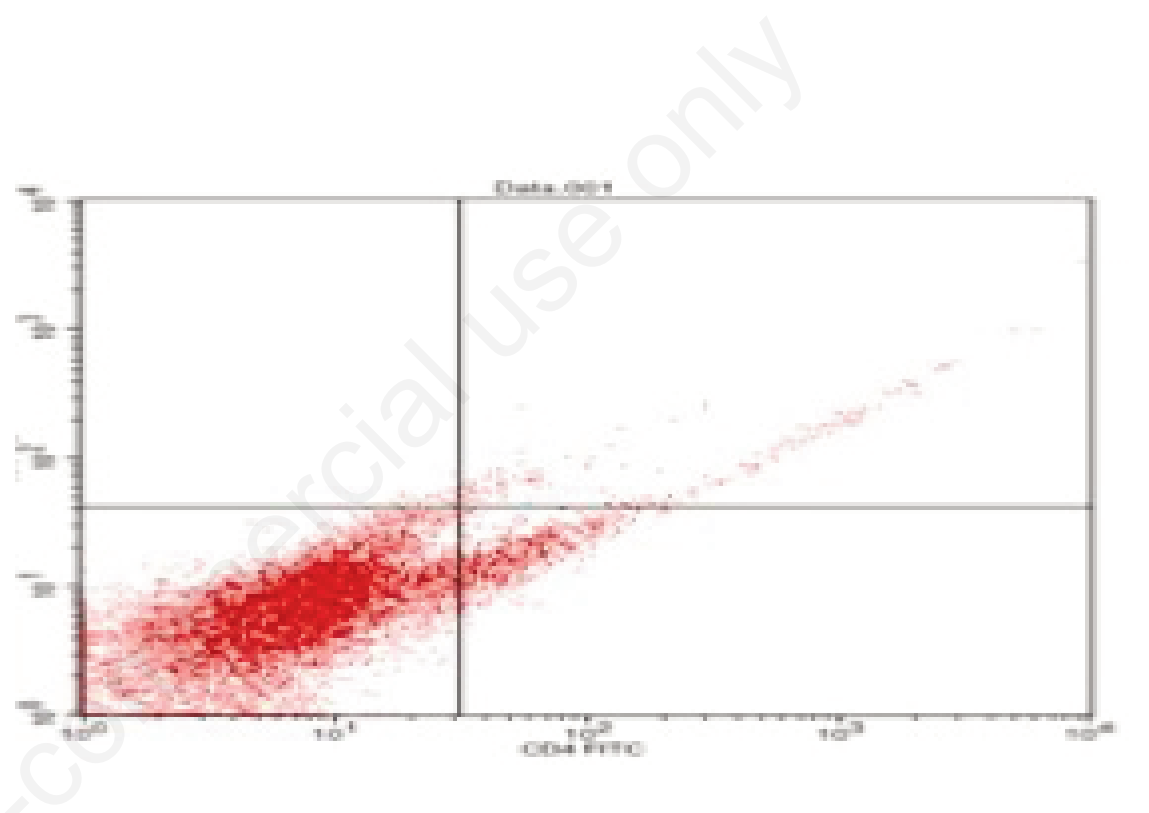

Figure 1. T lymphocyte $\left(\mathrm{CD}^{+}\right)$cells expression $(6.91 \%)$ in the saliva of Caries Free.

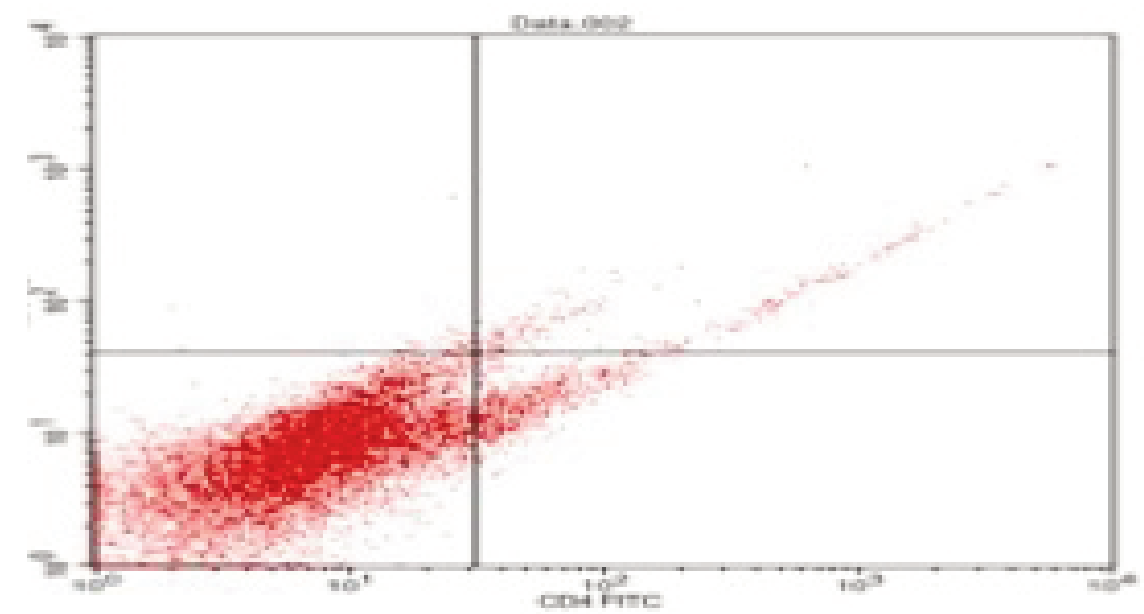

Figure 2. T lymphocytes $\left(\mathrm{CD4}^{+}\right)$cells expression $(5.60 \%)$ in the saliva of S-ECC. 
DPBS and $1 \%$ FCS, cells were centrifuged for 8 minutes at $1800 \mathrm{rpm}$ and the supernatant were removed. The cells were once again vortexed and $100 \mu \mathrm{L}$ of reagent a was added into the sample and cooled for 10 minutes. $50 \mu \mathrm{L}$ of mixture that had been fixated in reagent A was added into each samples and covered with aluminum foil and stored in refrigerator until acquisition at LSR2 flow cytometry.

The stained lymphocytes were analyzed using flow cytometer (LSR 11 Sorvall RT7 Plus, Becton Dickinson, USA) with cell quest software (Becton Dickinson, USA). The results were analyzed using flow Jo 7.0 (USA) software. The expression of $\mathrm{CD}^{+}$ were analyzed using standard FACScan procedure with mAbs according to the producer protocol. The results are calculated and presented in mean.

\section{Statistical analysis}

The acquired data was analyzed the normality and homogeny, then followed by Ttest to find the difference between two groups, with the level of significance at 0.05 .

\section{Results}

Data normality test using shapiro-Wilk obtained $\mathrm{P}$ value of expression of T lymphocytes $\left(\mathrm{CD}^{+}\right)$of 0.200 while the value of $p$ value of CD4 of 0.345 shows that both $\mathrm{P}$ values $>0.05$ which means the data are normally distributed, because the data are normally distributed then a comparative test is then performed a comparative test between groups using the independent $\mathrm{T}$ test.

In Table 1 shows that the mean expression of T lymphocytes (CD4 +) in S-ECC higher than caries free children.

Comparative test results of $\mathrm{T}$ lymphocyte $(\mathrm{CD} 4+)$ cell expression between the SECC and free caries groups showed a Pvalue of 0,000 , which is smaller than 0.05 $(\mathrm{P}<0.05)$, which means that there are significant differences between the S-ECC and free caries groups (Figures 1-4).

\section{Discussion}

Steptococcus mutans (S. mutans) is the main bacterium that has a strong relationship with ECC while other oral bacteria in dental biofilms can be involved in the initiation and development of caries. ${ }^{16}$ Other bacteria associated with ECC are the Lactobacillus species which play an important role in the development of lesions. ${ }^{17}$ Actinomyces species, especially
Actinomyces gerecseriae, are also associated with caries initiation. In addition, some non-mutans streptococci that have acidogenic and aciduric properties are also associated with dental caries. Epidemiological data indicate that in the pathogenesis of dental caries, Candida albicans also plays an active role. ${ }^{18}$.

T lymphocyte cells (CD4 +), known as helper $\mathrm{T}$ cells, are effector cells for cellmediated immunity. T lymphocytes (CD4 + ) are naive and must be activated to start effector functions, this activation occurs through interactions with professional anti-

Table 1. Mean and standard deviation of the expression of T lymphocytes (CD4 +) after 24-hour incubation were analyzed by flow cytometry test and statistical test $t$.

\begin{tabular}{lcccc} 
No & Group & N & $\begin{array}{c}\text { CD4+expression } \\
\text { Mean (X) SD }\end{array}$ & P-value \\
\hline 1 & S-ECC & 8 & 6.25250 .64482 & 0.0000 \\
2 & Free Caries & 8 & 8.41381 .10397 & \\
\hline
\end{tabular}

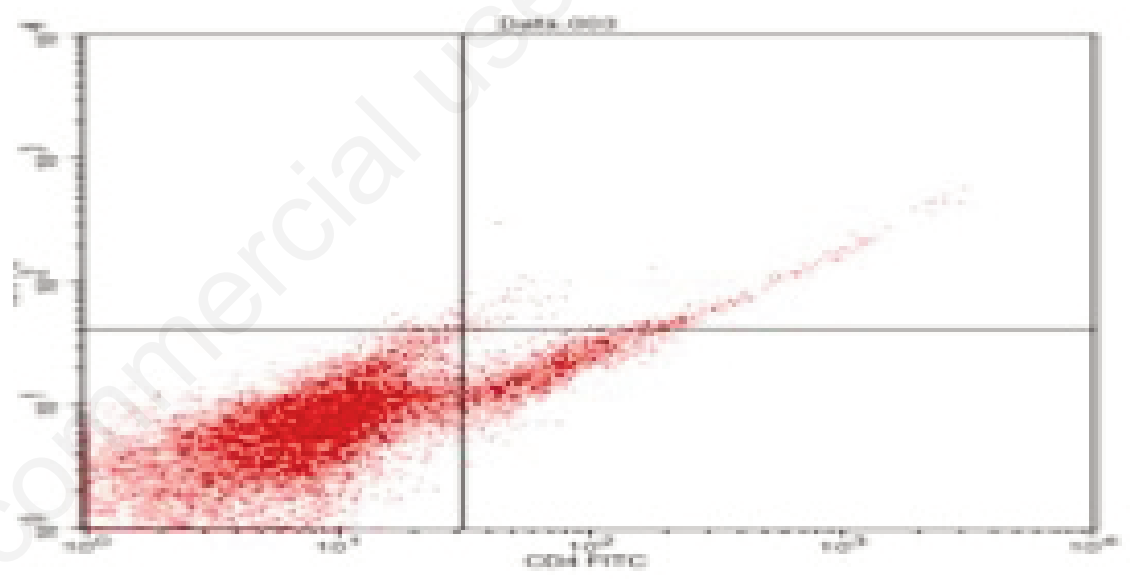

Figure 3. T lymphocytes $\left(\mathrm{CD}^{+}\right)$cells Expression $(10.24 \%)$ in the saliva of Caries Free.

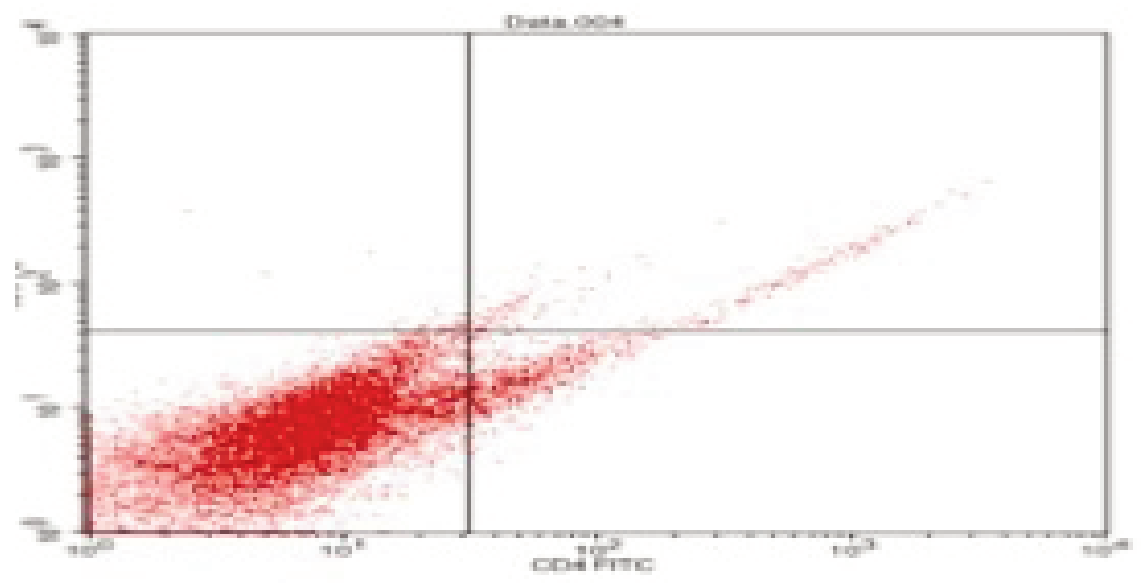

Figure 4. T lymphocytes $\left(\mathrm{CD}^{+}\right)$cells Expression (6.64\%) in the saliva of S-ECC. 
vate $\mathrm{B}$ cells to produce immunoglobulins in response to antigens..$^{19,20}$ The results of the study as shown in Table 1 show that the expression of $\mathrm{T}$ lymphocytes $\left(\mathrm{CD}^{+}\right)$cells in S-ECC is significantly lower than in free caries, this may cause the high $S$. mutans bacteria found in S-ECC saliva cannot be in acquisition by adaptive immunity because TCR and its co-receptors, such as CD4 which can form complexes with class 2 major receptor histocompatibility complex (MHC) receptors and antigens, cannot function optimally so that quantitatively the number of $S$. mutans which are bacteria that causes caries is higher compared to cariesfree children. ${ }^{21}$ Expression of $\mathrm{T}$ lymphocytes $\left(\mathrm{CD}^{+}\right)$in $\mathrm{S}-\mathrm{ECC}$ causes the release of pro-inflammatory cytokines that function as chemoattractant of neutrophil cells, because the movement of neutrophils toward the infection area is less than optimal, the movement of macrophages is also less than optimal towards the area of infection, giving $S$. mutans the opportunity to develop and do damage to the teeth.

In addition to the above, the low expression of CD4 + T lymphocyte cells in S-ECC results in slow $\mathrm{B}$ cells forming antibodies. This happens because CD4 + T cells recognize antigens well and can activate $B$ cells to produce antibodies in the form of immunoglobulins in response to $S$. mutans antigens.

\section{Conclusions}

In S-ECC there is a decrease in T lymphocyte $\left(\mathrm{CD}^{+}\right)$expression.

\section{References}

1. Naidu R, Nunn J, Donnelly-Swift E. Oral health-related quality of life and early childhood caries among preschool children in Trinidad. BMC Oral Health 2016;16:1-9.

2. Abanto J, Carvalho TS, Mendes FM, et al. Impact of oral diseases and disorders on oral health-related quality of life of preschool children. Community Dent Oral Epidemiol 2011;39:105-14.

3. Casamassimo PS, Thikkurissy S, Edelstein BL, Maiorini E. Beyond the dmft: the human and economic cost of early childhood caries. J Am Dent Assoc 2009;140:650-7.

4. Dye BA, Li X, Thorton-Evans G. Oral health disparities as determined by selected healthy people 2020 oral health objectives for the United States, 20092010. NCHS Data Brief 2012;(104):18.

5. Dye BA, Hsu K-LC, Afful J. Prevalence and Measurement of Dental Caries in Young Children. Pediatr Dent 2015;37:200-16.

6. Amalia R. Indonesia. In: Folayan MO (ed). A Compendium on Oral Health of Children Around the World: Early Childhood Caries. New York, NY: Nova Biomedical; 2018. pp. 155-65.

7. Sutjipto RW, Herawati H, Kuntari S. The prevalences of early childhood caries and severe early childhood caries in preschool children at Gunung Anyar Surabaya. Dent J 2014;47:186-189

8. Colak H, Dülgergil CT, Dalli M, Hamidi MM. Early childhood caries update: A review of causes, diagnoses, and treatments. J Nat Sci Biol Med 2013;4:29-38.

9. Liang Y, Chen X, Chen J, Liu F. Differentiation and function of $t$ cell subsets in infectious diseases. J Immunol Res 2018;2018:2-4.

10. Zhen A, Krutzik SR, Levin BR, et al. CD4 ligation on human blood monocytes triggers macrophage differentiation and enhances HIV infection. J Virol 2014;88:9934-46.

11. Artyomov MN, Lis M, Devadas S, et al. CD4 and CD8 binding to $\mathrm{MHC}$ molecules primarily acts to enhance Lck delivery. Proc Natl Acad Sci USA 2010;107:16916-21.

12. Doyle C, Strominger JL. Interaction between CD4 and class II MHC molecules mediates cell adhesion. Nature 1987;330:256-9.
13. Jonsson $\mathrm{P}$, Jennifer $\mathrm{H}$, Southcombe, et al. Remarkably low affinity of CD4/peptide-major histocompatibility complex class II protein interactions. Proc Nati Acad Sci USA 2016;113: 5682-5687.

14. Luthfi M, Setijanto D, Rahardjo MB, et al. Correlation between human neutrophil peptide 1-3 secretion and azurophilic granule (CD63) expression in early childhood caries. Dent Res J 2019;16:81-6

15. Luthfi M, Oki AS, Indrawati R, Latuamury NS. Analysis of Lymphocyte Cell Proliferation and IFN$\gamma$ Expression In Saliva of Severe Early Childhood Caries and Caries-Free in Surabaya. Malaysian Journal of Medicine and Health Sciences 2019;15:8-10.

16. Hajishengallis E, Parsaei Y, Klein MI, Koo H. Advances in the microbial etiology and pathogenesis of early childhood caries. Mol Oral Microbiol 2017;32:24-34.

17. Li Y, Tanner A. Effect of Antimicrobial Interventions on the Oral Microbiota Associated with Early Childhood Caries. Pediatr Dent 2015;37:226-44.

18. Anil S, Anand PS. Early childhood caries: Prevalence, risk factors, and prevention. Front Pediatr 2017;5:1-7.

19. Shen $\mathrm{H}, \mathrm{Wu} \mathrm{N}$, Nanayakkara G, et al. Co-signaling receptors regulate $\mathrm{T}$-cell plasticity and immune tolerance. Front Biosci Landmark Ed. 2019;24:96-132.

20. Bourne N, Perry CL, Banasik BN, et al. Increased Frequency of Virus Shedding by Herpes Simplex Virus 2-Infected Guinea Pigs in the Absence of $\mathrm{CD}^{+} \mathrm{T}$ Lymphocytes. J Virol 2019;93:1-11.

21. Luthfi M, Indrawati R, Arundina I, Dachlan YP. Korelasi Jumlah Streptococcus mutans (S. mutans) dan Level Ekspresi Interlukin 8 (IL-8) pada Severe Early Childhood Caries. Maj Kedokt Gigi Indones 2015;20:142. 